\title{
Jeden model, různé zájmy Konvergence a divergence intermediálních studií
}

\author{
Alice Jedličková
}

\section{AbStract \\ One model, many interests \\ Convergencies and divergencies in intermedia studies}

The essay provides a thorough analysis of the method and possible impact of the recent monograph Media transformation (2014) by Lars Elleström, a major representative of intermedia studies. The aim of the analysis is to evaluate possible consequences of Elleström's model of media transformation - regarded as a methodological basis of intermedia approach - for the study of wide range of cultural phenomena (as suggested by the author himself), at the same time taking into consideration his concept of media modalities used as a set of tools to be employed in individual intermedia problems inquiries. The idea of a methodological basis capable of unifying research in new media, adaptation studies, and literature-oriented intermediality appears rather utopian, since it may hardly overcome the differences and interests of individual disciplines. Yet the ongoing reflection of notions and categories in the field of intermediality (employed both in scholarly analyses and intermediality classes at the Masaryk University) provides a number of incentives for further research.

\section{KEYWORDS}

Intermediality, transmediation, media representation.

\section{KLÍčOVÁ SLOVA}

Intermedialita, transmediace, reprezentace média. 


\section{Metodologická východiska. Elleströmův systém modalit}

Název stati Wernera Wolfa „Intermedialita, široké pole výzkumu a výzva literární vědě“ (2002, česky 2011) prozrazuje, že její ambicí bylo přesvědčit literární vědce o účelnosti intermediálního přístupu v době, kdy se teprve dostával do jejich povědomí. Ke zpřehlednění onoho širokého pole se autor pokusil přispět teoretizací a základní typologií intermediálních vztahů na převážně sémiotické bázi. Stanovil si také úkol, který je nám blízký a který průběžně sledujeme: ověřovat důsažnost intermediálního přístupu pro literárněvědné bádání a obráceně, posuzovat, jakým způsobem a nakolik může literární věda přispět intermediálnímu výzkumu. Ohnisko svého zájmu přitom vymezil jako „intermediální výzkum soustředěný na literaturu (literaturzentrierte Intermedialitätsforschung) “ (WOLF 2011: 62). Právě tento zřetel a jeho poctivé dodržování nás vedly jednak $\mathrm{k}$ představení a komentování Wolfových prací v českém kontextu (srov. WOLF 2011, 2013, FEDROVÁ - JEDLIČKOVÁ 2011 ad.), jednak k jejich co možná operativnímu využití v seminářích intermediálních studií. Lze říci, že v současnosti už tato výzkumná orientace představuje určitou odnož intermediálních studií: nezapře své genetické nebo alespoň genealogické vazby $\mathrm{k}$ předchůdným interart studies s jejich dominantním zájmem o vztahy mezi literaturou, výtvarným, resp. dalšími vizuálními uměními a hudbou, a ukotvena je hlavně v německojazyčné anglistice a amerikanistice. ${ }^{1}$

Do jisté míry spřízněné badatele najdeme i v intermediálním výzkumu skandinávském, z nějž vzešly některé ze zakladatelských prací, spojené hlavně se jménem Hanse Lunda (srov. LUND et al. 1997). Také Lars Elleström (Linnéova univerzita v Kalmaru a Växjö) se vždy hlásí k zázemí literární a filmové vědy ke zkoumání moderní poezie a ironie v literatuře, $\mathrm{k}$ otázkám filmové adaptace, jakož i k sémiotickým základům své metody (soustavně se zabývá problematikou ikonicity). Současně však patří k těm, kdo intermediální metody a pojmosloví průběžně reflektují a revidují (svědčí o tom jeho nejnovější studie prověřující pojmový vztah ikonicity v poezii a vizuální poezie). Navíc však patří $\mathrm{k}$ těm několika málo, kteří dlouhodobě, důsledně, ba s jistou zarputilostí usilují o takovou teoretizaci intermediálních jevů, jež by dovolila nabídnout společnou platformu široce pojatému intermediálnímu bádání.

1) Svědčí o tom třeba kolektivní publikace Handbook of Intermediality (RIPPL 2015), působení Centra intermediálních studií na univerzitě ve Štýrském Hradci (CIMIG) pod vedením Wernera Wolfa, nebo edice tematických svazků Studies in Intermediality, od 2006 v nakl. Rodopi, nyní Brill. 
V metodologickém úvodu kolektivní monografie Media Borders, Multimodality and Intermediality (2010) předložil Elleström velmi užitečný nástroj popisu a konfrontace jednotlivých médií rozvržením systému tzv. modalit (podrobný rozbor viz JEDLIČKOVÁ 2010, 2011). Vycházeje z předpokladu, že každé médium je tvořeno určitým komplexem základních vlastností a intermediální je v tom smyslu, že je zřejmé a vysvětlitelné právě ve vztahu k ostatním typům médiú, s nimiž může komunikovat a kooperovat, vymezil obecné parametry konstitutivních vlastností médií, které současně vytvářejí podmínky pro onu komunikaci a kooperaci. Stanovil je jako čtyři univerzální (resp. „transmediální) mediální modality. Určit modalitu materiální znamená popsat, z čeho jsou produkty daného média tvořeny (například mluvená řeč a hudba sdílejí jako materiální modalitu zvukové vlny nesené vzduchem). Modalita smyslová je shrnutím způsobů vnímání produktů daného média, tj. kterým smyslem nebo kombinací smyslů je recipujeme (například tištěné písmo a malbu vnímáme zrakem). Modalita časoprostorová ukazuje, jak se produkty daného média realizují v prostoru a čase (např́klad tanec a film v nutně souvislém časovém úseku). A konečně modalita sémiotická určuje, který typ reprezentace je pro produkty daného média dominantní či typický (například ikonicita ilustrací v naučné knize pro děti nebo ikonické značky na pracovní ploše počítače odkazující k souboru pomůcek uživaných v tradiční kancelářské praxi). Jednotlivá média jsou pak ve svých konstitutivních vlastnostech, tj. jako tzv. základní média (basic media) určena právě konstelací těchto čtyř modalit. Jako technická média (technical media) vymezuje Elleström objekty a jejich soustavy, které slouží k manifestaci a distribuci produktů jednotlivých médií. V historickém vývoji a za určitých kulturních a technologických podmínek se základní média postupně „kvalifikovala“ například v postavení umění (s dominancí estetické funkce) či sdělovacích prostředků (s dominancí časné a plošné distribuce informací). Historicky a kulturně ukotvená, institucionalizovaná média s relativně ustáleným vztahem komunikační a estetické funkce označuje proto Elleström jako média kvalifikovaná (ELLESTRÖM 2010: 17-24) 2 ${ }^{2}$ Tyto parametry klasifikace médií zde specifikujeme ze dvou důvodů: jednak jako názornou ukázku nástroje aplikovatelného v seminární praxi, jednak si jím připravujeme cestu k rozboru metody jeho následující monografie Media Transformation (2014). Autor se v ní sice k výkladu

2) V recenzi tohoto svazku (JEDLIČKOVÁ 2011) i v následné aplikaci modalit (JEDLIČKOVÁ 2011a) jsem termín qualified media $\mathrm{v}$ rozpacích z personifikujících konotací přeložila volněji - byt’ se souhlasem autorovým - jako kontextualizovaná, tj. rozuměj kulturním a historickým kontextem vymezená. Po další diskusi reviduji na doslovnější kvalifikovaná a připouštím onu personifikaci, v jejímž rámci se média „kvalifikují“, tj. vyjednávají si určité postavení v kulturní komunikaci. 
modalit vrací, ale činí tak v krátkém přehledu až ve čtvrté kapitole (2014: 3739), zde však povědomí o jejich soustavě potřebujeme jako výchozí předpoklad dalších úvah o tom, jak tato novější práce může plnit ony dva úkoly naznačené v průkopnické stati Wernera Wolfa.

\section{Genetická perspektiva}

V monografii Media Transformation (2014) Elleström ze dvou základních možností zkoumání intermediálních vztahů, tj. perspektivy synchronní, a tedy zaměření na koexistenci mediálních produktů a způsoby kombinace a integrace vlastností jednotlivých médií, a perspektivy diachronní, která podle něj znamená sledovat oblast realizovaných nebo potenciálních mediálních přenosů, volí alternativu druhou. Vzhledem $\mathrm{k}$ povaze jeho přístupu bychom zde před jeho vlastním označením diachronní dali přednost adjektivu genetický - autorova klasifikace totiž může snadno vyvolávat dojem, že bude přihlédnuto k vývoji médií či historicitě pojednávaných mediálních transformací, to ale rozhodně není součástí jeho záměru. Naopak, jde mu primárně o zobecnění mechanismů mediální transformace, a specifikacím, neřkuli usazování jednotlivých jevů v konkrétním kulturním a historickém kontextu, se výslovně brání. (My se k této strategii naopak ve snaze ozřejmit konkretizací povahu sledovaného problému leckdy uchýlíme.) Podle Elleströma to logicky vyplývá z antiesencialismu, který považuje za jeden $\mathrm{z}$ hlavních rysů intermediálních studií: většina jejich pojmů totiž podle něj vyjadřuje mnohem spíše myšlení o médiích než povahu jejich bytí. Jednak lze namítnout, že úplně stejně bychom přece mohli uvažovat i o zavedených pojmech literárněvědných, jednak tím autor trochu protiřečí svému konceptu modalit: vždyt právě ony jsou určeny k tomu, aby nám dovolily popsat způsoby bytí média. Jako logické se ovšem jeví, že tři analýzy uzavírající monografický výklad - pro českého vnímatele potěšitelně věnované tvorbě Švankmajerově - jsou mnohem více než případovými studiemi exemplifikacemi či ilustracemi obecných mechanismů mediální transformace.

Postup Elleströmova výkladu je řízen dvěma faktory: jednak zobecňujícím záměrem, jednak předpokladem poměrně vysoké míry recipientovy povědomosti o předchozím vývoji intermediálního přístupu. Pojem médium tu proto možná nepřekvapivě zůstává slepou skvrnou výkladu a výchozí výčet př́íladů - 
zahrnující „takzvané umělecké formy (literatura, hudba, film atd. ) “ i „jiné typy médii““ (jako je „řeč, gestikulace, blogy, zprávy nebo reklama, at už jsou vnímány jako estetické či nikoli“, ELLESTRÖM 2014: 2) - rozhodně nenabídne čtenáři názornou představu, jakými parametry je médium vymezeno, nýbrž spíše domněnku, že jako médium může být vnímána celá řada jevů kulturní komunikace. Ve výčtu se totiž střídají umění, jimž Elleström v dřivějším výkladu přisoudil status historicky a kulturně vymezených, tj. v kulturní praxi kvalifikovaných médií (literatura), znakové soustavy schopné plnit jen omezený repertoár spíše doprovodných komunikačních funkcí (gestikulace) a třeba mediální žánry (internetový blog). Pojem média se tak napohled rozšiřuje na všechno, co je schopno nést nějakou informaci.

\section{„Mapování prostoru“: prozatím pozastaveno}

Výše citovaný titul jedné z úvodních podkapitol (2014: 7-10) slibuje popis stavu výzkumu, autor se však pouští do stručné kritiky výběru prací, které mu mohly svého času být blízké svým „literaturocentrismem“ (RAJEWSKY 2002, WOLF 1999) a/nebo úsilím o teoretizaci jevů a systemizaci pojmosloví (zvl. WOLF 2002, 2002a). Na druhé straně se poněkud překvapivě obrací i k příspěvkům, které jsou jeho bádání vzdáleny jak centrální oblastí zájmu (nová média), tak přístupem (zvl. BOLTER - GRUSIN 1999). Rozbor většiny těchto konfrontací ponecháváme na závěr: odhaluje totiž silná i slabá místa Elleströmova vlastního výkladu a současně ukazuje několik významných rysů (inter)mediálních studií i možností jejich uplatnění.

Jeden z aspektů Elleströmovy kritiky však zmíníme už ted': jeho razantní odmítnutí Wolfova dělení intermediality na strukturní (werkintern, srov. WOLF 2002, resp. intracompositional, 2002a) a relační (werkübergreifend, extracompositional, WOLF 2002 a 2002a, české ekvivalenty in 2011). Podle Elleströma se tím tvrdí, že zatímco některé intermediální rysy nacházíme uvnitř mediálních produktů, jiné mimo ně; médium tak ve výsledku nabývá charakteru „nádoby“ se zjevným „povrchem“ a „obsahem“. Ani autor sám se tomuto - mnohdy ostatně heuristicky účelnému - dělení, jak ještě vícekráte uvidíme, vyhnout nedokáže. Má však pravdu v tom, že každý intermediální jev (a to zvláště takový, jehož povahu dovedeme určit až analýzou struktury díla, jako například tzv. muzikalizaci 
prózy ve Wolfově klasifikaci (WOLF 1999), tj. přenos hudební kompozice do výstavby vyprávění) je současně relační v tom smyslu, že jej rozpoznáme na základě znalosti dalšího média a kompetence porovnávat vlastnosti médií.

\section{Základní dělení: transmediace a reprezentace médií}

Právě z nevyhnutelné souvztažnosti médií vychází i Elleströmovo základní dělení transformace médií na transmediaci a reprezentaci médií (2014: 11-35). Nejprve vymezuje mediaci, pod kterou rozumí materiální proces, jímž technické médium jako materiální nosič a prostředek distribuce zprostředkuje presémiotické smyslové konfigurace: například tištěná stránka v knize zprostředkuje vizuální konfiguraci, kterou vnímatel rozpozná jako báseň nebo diagram. Právě tady se ukazuje jedno z úskalí Elleströmova modelování: vydělení „presémiotické“ složky mediace je totiž nanejvýš umělé, protože vlastně - byť v pomyslném procesu fungování mediálního produktu dočasně - popírá jeho znakovou povahu. Ve starší práci (2010) mluví Elleström také o vztahu mezi technickým a základním médiem jako o mediaci bez signifikace. Proces tvorby významu označuje jako reprezentaci. Připomíná, že reprezentace leží v základu našeho myšlení: mediální smyslové konfigurace jsou zdrojem podnětů, které jsou kognitivními procesy importovány do naší mysli, a ta generuje význam.

Jestliže jsou určité smyslové konfigurace zprostředkované jistým technickým médiem schopny vyvolat reprezentaci odpovídající konfiguraci uskutečněné už dřive $v$ jiném médiu, znamená to, že jsou transmediovány. Situaci se Elleström snaží znázornit také s využitím peirceovského pojetí znaku: transmediace znamená, že representamen cílového média vyvolá v mysli vnímatele přibližně týž objekt, jako representamen média zdrojového. Např́iklad tištěná báseň je následně přednesena, tzn. základní charakteristiky básně jsou zprostředkovány jiným typem smyslové konfigurace, nikoli vizuálními, nýbrž auditivními znaky. - Tady se Elleström opět dost rozchází s pojetím Wolfovým, podle nějž je podmínkou mediální transpozice (transmediace) změna nebo multiplikace sémiotického systému. $V$ přednesu básně však $\mathrm{k}$ takové změně nedochází; na druhé straně nelze popřít, že jej provázejí další významotvorné prvky řeči (například suprasegmentální), a jejich působením dochází tedy $\mathrm{k}$ další signifikaci - tady zase shledáváme 
argument ve prospěch postoje Elleströmova. - Transmediace ve svém důsledku vždy znamená také určitou míru transformace reprezentovaného - verbální popis (description) téhož objektu nikdy nebude identický s jeho vizuálním zobrazením (depiction); srov. 2014: 15.

Byt’ se v praxi prostupují, je pro Elleströma zásadním krokem teoretické rozlišení transmediace od reprezentace média: tou rozumí případ, kdy jedno médium směruje jakýmkoli způsobem reprezentace naši mysl k jinému médiu; zase přitom dochází $\mathrm{k}$ různým transformacím, proto by vlastně bylo na místě mluvit o „transmediální reprezentaci média“. Reprezentace média v různé míře pokrývá jak médium samo, tak jeho obsah (content) - například popis fotografie se může věnovat tomu, jak vypadají jednotlivé části zobrazeného předmětu, i kompozici fotografie, tedy zobrazovací technice média. Jak je vidět z předchozí formulace, vykladačské pasti „nádoby“ a jejího „obsahu“ autor přes svi̊j houževnatý odpor nedokáže nikdy uniknout (a klademe si otázku, je-li to vůbec možné). My však nedovedeme uniknout pasti mnohem zákeřnější, kterou nám ve schematizaci transmediačního procesu autor nastražil svým opisem toho, co je obecně predmětem transmediace: označuje totiž tuto entitu media characteristics. Jakýkoli pokus o blízký překlad se jeví jako zavádějící. Po diskusi v rámci projektu ${ }^{3}$ volíme nakonec ekvivalent mediát, vytvořený analogicky k modelu jazykové komunikace a označující tedy jakkoli rozsáhlý mediálně distinktivně strukturovaný významotvorný celek. Pak už můžeme spolu s autorem načrtnout schéma rozdílu mezi transmediací a reprezentací média: $v$ prvním případě cílové médium (znovu) reprezentuje týž mediát jako zdrojové médium, zatímco v případě druhém cílové médium reprezentuje zdrojové médium samo, nebo jinak řečeno, zdrojové médium se stává mediátem média cílového. Reprezentace může zahrnovat jak vlastnosti kvalifikovaného média, tak současně i konkrétního mediálního produktu (například román může pojednávat o hudbě jako takové i o konkrétní skladbě).

Další úroveň rozlišování, kterou Elleström předkládá, totiž prostá a komplexní transmediace (2014: 21nn), vyvolávají rozpaky, a to tím silnější, o co razantněji se autor sám v kritice předchůdců vymezuje vůči vágním klasifikacím. Prostá transmediace kvalifikovaných médií podle něj odpovídá transmediaci jednoduchého obsahu z jednoho média do druhého. Tento mechanismus lze podle něj také chápat jako vztah celých množin mediátů se srovnatelným obsahem (např́klad vztah souboru článků o jablkách a souboru fotografií jablek).

3) Viz závěrečná dedikace. Za nápad vděčím kolegovi Tomášovi Chudému. 
Zaprvé opravdu nechceme být tak zlomyslní, abychom autora znovu přistihovali při dělení média na „nádobu“ a „obsah“. Ale hlavně už tady, ale tím spíše u dalšího př́ikladu, totiž prosté transmediace mediálního produktu, vznášíme námitku, že tato situace, zdá se, odpovídá také nebo ještě spíše oné synchronní, paralelní existenci mediálních jevư, o níž se mluví na samém začátku výkladu. Prostou transmediaci Elleström exemplifikuje mediálním transferem „příběhu štastlivce, který upadne do neštěstí", nebo výskytem téže postavy v televizním programu a graphic novel. To ale mohou být kategorie odlišného řádu: v prvním případě jde o vysoce konvencionalizovanou narativní strukturu, jaké se snažila popsat a dále dělit strukturální naratologie v návaznosti na Proppovu morfologii pohádky coby narativního žánru; teoretik vyprávění Abbott nazval tyto obecné konstrukce vzhledem $\mathrm{k}$ jejich $\mathrm{k}$ oblíbenosti a rétorické účinnosti jejich využití v nejrůznějších diskurzech masterplots (2006). ${ }^{4} \mathrm{~V}$ případě druhém není jasné, zda je míněn $\mathrm{v}$ dané kultuře ustálený typ postavy (tř̀eba hloupý Honza $\mathrm{v}$ české pohádce nebo nenapravitelný blbec $\mathrm{v}$ mainstreamovém filmovém žánru crazy comedy - pak by př́klad byl přijatelný); anebo zda jde o individualizovanou, v daném kulturním prostředí „ikonickou“ postavu, například některého ze superhrdinů) jako je Batman. Ten se, jako mnoho dalších, stal díky své oblíbenosti výhodným obchodním artiklem a přesouvání této postavy a s ní spojených syžetových schémat mezi médii je typickým dokladem tzv. „franšízování kultury“ (culture franchising v terminologii Henryho Jenkinse, 2006, nebo repurposing v terminologii Bolterově a Grusinově, 1999). Takový pohyb v prostoru kultury by asi bylo možno znázornit genealogickým stromem, v němž by nám vystopování vazeb mezi jednotlivými médii a mediálními produkty dovolilo právě sledování mechanismu franšízování; nejčerstvější příklad takového typu „genealogické transmediace“, která je současně franšízou batmanovské látky, najdeme v příznačném titulu The Lego Batman Movie (režie Chris McKay, 2017). Superhrdinské příběhy (obvykle komiksového původu) ovšem představují příklad vysledovatelného genetického vztahu mezi médii. Obecné konstrukce typu masterplots však už do genetického vztahu či linie obvykle zařadit nedokážeme. Patři totiž k celé množině mediálně nespecifických formálních či obsahových konceptů a jejich konfigurací (často nadčasových a interkulturně

4) Abbottova terminologická volba je motivována snahou zbavit se konotací spojených s alternativními označeními jako archetypální či kanonický příběh. Hodnotové konotace spojené s první složkou jím navrženého termínu (master) jsou pro nás zbytné, a naopak si dovolíme mírný posun v interpretaci druhé složky pojmu (plot), již autor volí jako ekvivalent pro příběh s objasněním, že pro evropské naratology to znamená spíše konstrukční složku narativního diskurzu, tedy „zápletku“ - právě tento důraz na konstrukci (uměle) oddělenou od traktovaných hodnot je adekvátní potřebám našeho aktuálního výkladu. 
migrujících), jež Rajewská a Wolf shrnují pod pojmem transmedialita, s podstatnou argumentací, že v nich obvykle není rozeznatelný či pro smysl díla zásadní vliv jednoho konkrétního média nebo mediálního produktu (a tedy transpozice z jednoho do druhého, srov. WOLF 2011: 67). Elleströmova prostá transmediace tedy v tomto smyslu možná vyjadřuje totéž co „transmediální koexistence“; autor se $\mathrm{k}$ tomuto řešení ostatně v náznaku přiklání, když odkazuje k dalším příspěvkům, které se zabývají cirkulací určitých konstrukcí v „mediálním okruhu“" (srov. 2014: 23).

Komplexní transmediace kvalifikovaného média naopak předpokládá transmediaci četných aspektů zdrojového média do dalšího média či mediálního produktu. Ilustrace, které autor volí, však př́liš nepřesvědčují ani o komplexnosti (příkladem má být již zmiňovaná, v literatuře nepř́liš frekventovaná muzikalizace prózy, u níž jde často jen o dílčí transfer mediálních vlastností: například přenesení kompoziční struktury skladby spolu se závaznými proměnami tempa do výstavby vyprávění u Woolfové, srov. WOLF 1999), ani o tom, že jsou bezpečně rozlišitelné od reprezentace média. To naznačuje Elleströmova následující exemplifikace: akrylová malba může ve zpracování povrchu, perspektivě a podání barevných tónů a detailů vykazovat vlastnosti, které jí „dodávají vzhled fotografie“ (2014: 24). Zkusme navrhnout možné konkretizace Elleströmova výkladu: zjištujeme pak, že některé (převážně olejové) malby Ralpha Goingse výstižně využívají pro fotografii typického nepřirozeného zvětšení předmětu blízko objektivu, jiné svým barevným podáním asociují postupně se vytrácející snímky z Polaroidu, zatímco některé malby Gerharda Richtera „mohou působit jako“ amatérské snímky z dovolené (kompozičně neobratné a rozostřené), jiné jako sportovní snímky objektu v pohybu, zašlé fotografie $\mathrm{z}$ rodinného alba nebo dokonce jako rozřádkované snímky televizní obrazovky či nezřetelné reprodukce snímků z novin (využití existujících fotografií ostatně tvoří podstatnou složku Richterova konceptu i techniky tvorby). Takové malby jsou nepochybně transmediací celé řady vlastností výchozího kvalifikovaného média (nevyhnutelných důsledků $\mathrm{v}$ perspektivě zobrazení plynoucích $\mathrm{z}$ parametrů technického média, náhodných důsledků amatérského postupu při fotografování, nežádoucích efektů plynoucích $\mathrm{z}$ chemické nestability materiálního nosiče a obecně vnějších vlivů na materiál $\mathrm{v}$ čase atd.). Ale těžko se zbavit dojmu, že tu řešíme dva velmi odlišné př́ípady, nikoli příklady téhož: zatímco muzikalizovaná próza je výsledkem verbální transmediace mediálně (a žánrově) příznačných zákonitostí konstrukce hudebního díla, ale rozhodně se mu nepodobá, malby, jimiž konkretizujeme Elleströmův návrh, mohou vzhledem ke shodě zrakového vnímání 
a k blízkosti smyslových konfigurací obou médií (plošnost a dvourozměrnost, kontrasty světla a stínu, plochy a kontury, barevné nuance, jejich kompozice v zobrazení) „vypadat jako fotografie“. Neinformovaný divák je dokonce může zprvu považovat za zvětšeniny, tj. výsledný produkt malířství jako kvalifikovaného média na něj působí (byt’ na první pohled) jako produkt média jiného. V procesu vnímatelské recepce se pak jako první uplatní to, co bychom mohli nazvat „manifestní medialitou transmediovaného média“, totiž fotografie. (Byt’ nadále platí, že representamen transmediace vyvolává v mysli vnímatele zhruba týž objekt jako representamen zdrojového média.)

Tato mentální operace je samozřejmě do značné míry ovlivněna povědomostí o výtvarném umění a s tím spojenými očekáváními. Elleström ostatně připouští, že obecnost jeho úvah nedovoluje pojednat rozdílný interpretační dopad různých situací; jak se zdá v našem případě, může to být rozdíl dosti zásadní. Je totiž $\mathrm{k}$ diskusi, zda takováto transmediace (o jejíž genezi navíc víme, že jde obvykle o transmediaci konkrétního mediálního produktu) není současně reprezentací zdrojového média? O nutnosti diskuse svědčí čerstvý příklad z kulturní praxe: na nedávné retrospektivní výstavě Gerharda Richtera ${ }^{5}$ svědčilo pozorovatelské chování i debaty zaujatých, namnoze zjevně poučených návštěvníků mnohem častěji o fascinaci Richterovou malírskou technikou coby technologií reprezentace (vlastností) jiného média než o zájmu o jednotlivou malbu coby transmediaci konkrétní fotografie. Lze přitom předpokládat podstatný vliv kontextu: zatímco na výjimečné autorské výstavě se do popředí dostala právě otázka mediálně technologická a smyslové zkoumání materiality artefaktů (nutno dodat, že bezobsažné doprovodné komentáře od jiného přístupu leda odrazovaly), vystavení Richterovy malby Strýček Rudi (1965) v Lidické sbírce výtvarného umění může asi mnohem spíše vést $\mathrm{k}$ reflexi individuálního díla s jeho historickými a etickými aspekty (jehož součástí může být intuitivní chápání díla jako transmediace jedinečného mediálního produktu, totiž staré fotografie). S touto zkušeností a úvahami, jež vyvolává, se ovšem zdá o to obtížnější akceptovat Elleströmův kmenový příklad reprezentace média, jímž je podle něj ekfráze, která obvykle (ne však vždy!) vedle námětu malby ztvárňuje malbu samu. A to navíc často jen tematizací média a odkazy k jeho kontextu, zdaleka ne tak komplexní transformací vlastností zobrazovacích postupů, jako se děje ve fotorealistické malbě. Ale možná se ukáže, že rozhodujícím aspektem pro odlišení reprezentace od transmediace je pro Elleströma právě ona jednoduchá tematizace

5) Palác Kinských - Klášter sv. Anežky české, Národní galerie v Praze, 26. 4. - 3. 9. 2017. 
média samého, například $v$ titulu nebo prostřednictvím nějaké strategie mediálně příznačného rámcování.

K výsledku se postupně dobereme přes další položku Elleströmovy klasifikace, jíž je komplexní transmediace mediálních produktů. Ta se může týkat jak jednotlivých produktů (tj. jde o transmediaci v poměru 1:1), tak celých množin produktů sdílejících určité rysy (např́klad transformace bondovské látky a dějových schémat ve filmu, který není přímou adaptací jednoho konkrétního Flemingova románu; tedy transmediace v poměru $\mathrm{x}: 1$ ). Filmová adaptace literární předlohy představuje typický př́klad transmediace; avšak teoretici adaptace rozhodně nejsou připraveni nebo spíše ochotni vpravit svoje bádání do transmediačního rámce. Elleström tento stav přičítá jak vyhraněnosti předmětu jejich pozorování (film vnímaný jako autonomní produkt kvalifikovaného média s vysoce rozvinutou narativitou), tak teorie samé. Nějaké styčné body tu najdeme: například jedna z předních teoretiček adaptace Linda Hutcheonová (2006) s fenoménem transmediace pracuje, protože jí dovoluje rozlišit škálu adaptačních postupů: připouští proto i transmediaci bez adaptace ( $\mathrm{tj}$. v podstatě přenos transmediálních kvalit, tj. takových, k nimž není nutno hledat mediálně odlišné ekvivalenty v cílovém médiu).

V zásadě se nám však zdá, že dráhy obou teorií se čím dál tím více oddalují: zatímco teorie intermediality se zaměřuje hlavně na vnitřní mechanismy transmediace, trendem adaptačních studií je zvýšení zájmu o sociologickou problematiku přizpůsobení či podřízení produkce okolnostem kulturní komunikace, například aktuálním politickým mantinelům ( $v$ nichž se ideologicky přípustná adaptace klasického díla stává pojistkou k zajištění cesty díla k divákovi a současně výzvou k hledání nových výrazových možností pro jeho usouvztažnění se společenskou situací), ale i ekonomickým a technologickým možnostem filmové výroby apod. Zkušenost $\mathrm{z}$ odborné rozpravy i vysokoškolské praxe nám napovídá, že nejen reprezentanti adaptačních studií, ale i studenti orientovaní na audiovizuální média mají tendenci podřazovat veškerou transmediační problematiku týkající se filmového média adaptační perspektivě a jejím zavedeným schématům: například transferu $z$ modu telling do modu showing, který zavádí Hutcheonová (aniž by respektovala obsazenost této pojmové dvojice v tradiční teorii vyprávění, v níž označuje dva různé způsoby mediálně identického, totiž verbálního vyprávění) a který spolehlivě platí právě jen pro vyhraněné př́iklady narativity. - Jestliže se například tvůrci odvážného projektu videoinscenací Shakespearových sonetů The Sonnet Project NYC brání chápání jednotlivých děl jako „videozáznamů recitace“, nýbrž chtějíjim získat postavení „nezávislých filmů“ (viz http://sonnetprojectnyc. com/about/), pak nejde o žánrovou klasifikaci, na niž by bylo možno přímo ap- 
likovat poznatky adaptačních studií, nýbrž o vyjednávání pozice jedinečného uměleckého díla (resp. souboru děl), o strategii komunikování projektu na internetu. - O perspektivě funkčního průniku adaptačních studií s teorií intermediality lze proto pochybovat, a troufáme si soudit, že Elleströmův sjednocující návrh na tom nejspíš mnoho nezmění: rozštěpení se tu totiž nezakládá ani tak na metodologické odlišnosti, jako na oněch rozdílných zájmech výzkumu.

Transmediaci v poměru 1:1 ovšem Elleström nekonkretizuje filmovou adaptací literární předlohy, nýbrž konstruovaným příkladem filmové scény inscenující výjev z existující malby. Taková filmová scéna (například muž trhá rudé květy) může být podle něj „transmediací obsahu reprezentovaného média“ (2014: 25, kurzíva AJ), přičemž malba sama nemusí být reprezentována ani v nejmenším; mohou sice být „transmediovány nějaké její vlastnosti“ (IBID., kurziva AJ), „avšak taková transmediace mediálního produktu se liší od jeho reprezentace“, dodává autor (IBID.: 26). Rozvinutí názorné konkretizace se tu nezdá být příliš nápomocné vyjasnění: jestliže jsou předmětem filmové transmediace jen takové vlastnosti mediátu, jako je věcný obsah, kompozice a barevné rozvržení scény, tj. vlastnosti mediálně nespecifické (jež filmová scéna sdílí s malbou i fotografií) a hlavně nezbytné pro zachování koherence mediátu v transmediaci, pak intermediální vztah logicky rozpozná jen ten filmový divák, jemuž scéna asociuje známou malbu (příklad: Rembrandtova noční hlídka, režie Peter Greenaway, 2007). Pokud jsou však transmediovány nějaké vlastnosti mediálně specifické („piktoriální“), jako třeba pointilistická technika štětce převedená pomocí filtru nebo kompozice postav a práce se světlem v jednotlivých výjevech zmiňovaného Greenawayova filmu (tj. analogicky k předchozímu příkladu s fotorealistickou malbou „filmová scéna pak vypadá jako malba / asociuje malbu“), pak lze možná připustit, že se jedná o mediální referenci pomocí imitace postupu zdrojového média (v slovníku Rajewské, 2002). A není pak takováto formální reference přece jen určitým stupněm reprezentace média?

Elleström $\mathrm{v}$ dalším výkladu podob reprezentace (vystavěné analogicky $\mathrm{k}$ transmediaci počínaje prostou reprezentací média) tuto i naši předcházející úvahu („malba jako fotografie“) zčásti vyvrací příklady, u nichž se zdá, že splňují minimální nárok na již zmiňovanou tematizaci mediálního produktu či jeho rámcování: prostá reprezentace se podle něj může realizovat i pouhým odkazem na titul uměleckého díla (například Michelangelova Davida), mohli bychom říci jakousi reprezentační synekdochou. Jako další jednoduchý příklad uvádí fotografii osob v místnosti, na níž rozeznáváme na zdi v pozadí obrazy či plakáty; nebo popovou píseň citující telefonát. Klademe si ovšem otázku, co je v této 
souvislosti pouhou citací (čistou reprezentací) a co už transmediací: píseň Donny Summer The Hostage (1974) byla uvedena osamostatněným, úsečným úryvkem telefonátu únosce se ženou rukojmího, asociujícím typickou filmovou scénu; v písni skupiny Electric Light Orchestra Telephone Line (1976) je telefonní rozhovor zapojen do celku a tematizován nejen prostřednictvím komunikačních formulí, ale i technických parametrů citovaného média, jež jsou promítnuty do zvukové realizace písně (dochází tu proto vedle prosté tematizace minimálně k určité imitaci vlastností média), a konečně Hello, nedávný hit (2015) zpěvačky Adele, sice začíná ohlášením mluvčí a tedy aluzí na mediálně příznačnou komunikační rutinu, tematizaci média však obstarává hlavně vizualizace telefonování ve videoklipu, který se v populární hudbě postupně stal takřka nezbytnou součástí prezentace skladby.

\section{Komplexní reprezentace média a svébytnost ekfráze}

Předmětem komplexní reprezentace média nemůže být podle Elleströma nic jiného než konkrétní mediální produkt jako nosič všech aspektů kvalifikovaného média. Jako její emblematický příklad uvádí ekfrázi coby symbolickou (verbální) reprezentaci ikonické (vizuální) reprezentace. Připomeňme ostatně, že badatelská renesance tohoto tématu $\mathrm{v}$ osmdesátých letech minulého století patřila $\mathrm{k}$ těm nejdůležitějším rysům interartových studií a k podnětům ustavení studií intermediálních. ${ }^{6} \mathrm{~A}$ je to také jeden $\mathrm{z}$ fenoménů zásadně zajímavých pro literárněvědné zkoumání. Právě v této souvislosti však Elleström proponuje vcelku zbytnou kategorii, když z existence velkého množství básnických ekfrází (například ekfrází malby Pietera Brueghela st. Krajina s pádem Ikarovým) vyvozuje možnost mluvit o této množině jako o submédiu definovaném reprezentací jednoho jediného mediálního produktu. Vzhledem $\mathrm{k}$ tomu, že dominantním parametrem definice submédia se tu - na rozdíl od standardní konstelace modalit - stává určité téma či tematický celek, vymyká se tato klasifikace jak ostatním intermediálním kategoriím, tak aktuálnímu autorovu záměru obecného modelování. Jistě tu spolupůsobí dva faktory - jednak Elleströmův dřívější detailní zájem o ekfrázi, jednak skutečnost, že v západních literaturách (na rozdíl od tradice

6) Vývojem teorie ekfráze, který autor rekapituluje, se zde nebudeme zabývat (činíme tak jinde, srov. např. FEDROVÁ - JEDLIČKOVÁ 2008, 2016, 2016a). 
české) básnická ekfráze tvoři určitou subžánrovou skupinu i vývojovou linii literatury - to ovšem není důvod pro analogické, avšak v rámci klasifikace médií nesystémové vymezení submédia. A další protiargument: předmětem ekfrastické reprezentace může totiž být nejen individuální mediální produkt, tj. jedno konkrétní výtvarné dílo, ale celá skupina děl, která zdaleka nemusí být vymezena sdíleným námětem, ale i jiným společným jmenovatelem, jako je styl (např́ílad autorský), kompoziční či koloristické zásady určité umělecké školy apod. Toto pro zkoumání transferu reprezentačních schémat mezi dvěma médii (výtvarným uměním a literaturou) nanejvýš užitečné rozlišení zavedla Tamar Yacobiová (1995 ad.) a konceptualizovala je jako piktoriální model (i ten se může vyskytovat v minimální, obvykle konvenční podobě, jako je například charakteristika malby jako „krajiny v duchu vlámských mistrů“).

Elleström připouští, že ekfráze nemusí být výlučně reprezentací média, ale může zahrnovat i transmediaci coby transformovanou reprezentaci smyslově vnímatelných konfigurací. Znovu se nám proto vrací utkvělá myšlenka této úvahy: není tedy transmediace mediálních rysů fotografie do malby, která pak „vypadá jako fotografie“ nebo vyvolává „mediální klam“, současně také reprezentací média? Lze namítnout, že míra reprezentace média v ekfrázi se velmi liší a její prostředky jsou často založeny pouze na prosté referenci. Text ekfráze bývá nezř́idka převážně verbální reprezentací (tvưrčí deskripcí) původního předmětu zobrazení, popřípadě převyprávěním známého námětu malby, např́ílad mytologického příběhu, a úvahou nad jeho vyústěním, etickými aspekty, povahou ztvárněného světa apod. - gestem navozujícím reprezentaci média je třeba pouhý odkaz k titulu výtvarného díla v titulu básně, ke jménu malíře nebo vyznačení skutečnosti, že pojednáváno je umělecké či řemeslné dílo (proslula Keatsova Óda na řeckou vázu, 1819). Velmi často v ekfrasticky založené básni spíše než o reprezentovaný mediální produkt sám jde o interpretaci problému nebo účinků jím evokovaných, a spíše než o konkrétní médium v jeho specifičnosti o „umění jako takové“v kontrastu k jiným oblastem lidské činnosti. Názorným příkladem může být lyrická miniatura Wisławy Szymborské Vermeer (sb. Tady, 2009):

\footnotetext{
„Dokud ta žena z Rijksmusea

$v$ namalovaném tichu a soustředěnosti

mléko ze džbánku do misky

den po dni přelévá,

nezasluhuje si svět

konec světa."
} 
Kurzivami zde vyznačujeme prostředky explicitně odkazující k médiu: v titulu k známému a ceněnému tvůrci, $\mathrm{k}$ muzeu (galerii) jako instituci, která má autoritativní společenskou funkci v udržování profilu výtvarného umění jako kvalifikovaného média, uchovává díla samotná a formuje představu umělecké kvality a vývoje umění. A právě od nejobecnějšího poukazu na techniku tematizovaného média („namalovaný“) se v této básni odvíjí i mediálně založená sémantická hra: Báseň transmediuje do verbální podoby reprezentační sílu výtvarného díla, jeho schopnost vizualizovat absenci auditivních podnětů, reprezentovat cítěné, žité ticho a stav koncentrace. Právě pro takový typ ekfráze nejspíše platí Elleströmem spíše jen nadhozený názor Claire Barbettiové, podle níž to, co je reprezentováno, není výtvarné dílo, vizuální reprezentace, nýbrž vnímání vizuální reprezentace, které je přeloženo do verbální podoby a interpretováno (BARBETTI 2011, cit. dle ELLESTRÖM 2014: 35). Elleström souhlasí s prvním kognitivním aspektem, a sice že spisovatel kreativně transformuje své vidění obrazu, ale namítá, že to neimplikuje, že vnímatel ekfráze ji pak nutně chápe jako reprezentaci percepce a nikoli jako reprezentaci vnímaného objektu. Na příkladě Szymborské se dobře ukazuje, že ani jedno stanovisko, tj. ani Barbettiové, ani Elleströmovo, nelze univerzalizovat: Tato báseň může sice vnímatele vést $\mathrm{k}$ mentální vizualizaci obrazu, ale je to hlavně díky vodítkům, jež odkazují k známé, ba „notoricky známé“ malbě. Titul odkazuje synekdochicky k celému Vermeerovu dílu, rozmanitému v určité jednotě, a implicitně k vlastnostem, které tuto jednotu v rozmanitosti garantují. Ekfrastická reprezentace je v básni Szymborské podřízena konstrukci lyrické existenciální situace, z níž vzchází smysl textu: vycítění jistoty přirozeného řádu věcí jako jedné $z$ hodnot, která by snad mohla zachránit svět před (sebe)zničením.

\section{Předpoklady transmediace}

Elleström je vyvozuje ve třetí kapitole na základě čtyř mediálních modalit, jež jsme už připomínali v kontextu jeho starší práce (2010): Modality představují univerzální, transmediální vlastnosti médií, jež ve vzájemných konstelacích (Elleström je nazývá modality modes) určují jednotlivá média. Ilustrujme si to konkretizací modalit například u tisku: dvourozměrnost, plošnost materiální základny smyslově vnímatelné konfigurace, linearita uspořádání znaků vyža- 
dující jejich souvislé vnímání probíhající v čase, sémiotický systém jazyk jako soustava symbolických znaků. Přitom plošnost, dvourozměrnost jako projev materiální modality sdílí tištěný text s malbou, jeho smysluplné vnímání je podmíněno souvislou percepcí $v$ čase jako třeba $\mathrm{v}$ případě písně. Tyto mody jsou konstitutivními složkami médií a nejsou v procesech transformace ani transmediovány, ani reprezentovány. Na jejich základě však vznikají specifické celky, které transmediovány být mohou (například určitý typ kompozice) a fungují i jako entity kognitivní; spolu s Wolfem bychom je asi označili za „kognitivní rámce " nižšího řádu. ${ }^{7}$ Elleström je nazývá (z pohledu úsilí o adekvátní jazykový převod pojmového obsahu opět nepříliš štastně) compound media characteristics. Jde vlastně o ustálené mediální struktury, které jsou v recepci mediálního produktu abstrahovány ze smyslově vnímaných konfigurací a v procesu interpretace fungují jako prostředky přikládání významu těmto konfiguracím: máme jim proto primárně rozumět jako kategoriím kognitivním, které odpovídají sklonu naší mysli osvojovat si a interpretovat koherentní celky. Takovou povahu má například přiběh, který může být traktován („vyprávěn“) různými mediálně specifickými prostředky (verbálním vyprávěním, výrazovým tancem apod.).

Zatímco záměrem první fáze Elleströmova výkladu bylo odlišit transmediaci od reprezentace média, popis celků, které jsou přenášeny, se stává předpokladem modelování mediálních transformací s ohledem na aspekty týkající se jednotlivých modalit a jejich konstelací i přenosu ustálených mediálních struktur (kap. 4). Elleström tu konstatuje vnitřní shodu s řadou teoretiků, u nichž specifický předmět zájmu a odlišné pojmosloví mohou vyvolávat dojem rozličnosti: tak je tomu například u teoretika filmové adaptace Briana McFarlanea, který rozlišuje „transfer“ (transfer) a „vlastní adaptaci“ (adaptation proper): „transfer je proces, v němž jsou určité narativní prvky románu identifikovány jako schopné prezentace ve filmu“, zatímco adaptace je „proces, v němž jiné románové prvky musí nalézt zcela odlišné ekvivalenty ve filmovém médiu, pokud jsou vůbec dostupné“ (McFARLANE 1996, cit. dle ELLESTRÖM 2014: 47-48). V prvním případě se tedy mluví o strukturách $\mathrm{v}$ zásadě transmediálních, zatímco $\mathrm{v}$ druhém o prvcích vázaných na jeden sémiotický systém. Současně je třeba v úsilí o objasnění transformačních procesů přihlížet jak k odlišné materialitě médií, tak k tomu, že - byt je podnícena smyslovými vstupy - je každá semióza proces v zásadě mentální.

7) Pro Wolfa je totiž jedním z významných aspektů definice média to, že funguje jako distinktivní kognitivní rámec. 
V transmediaci, zdůrazňuje Elleström, mohou být ustálené mediální struktury znovu reprezentovány, nemohou ovšem zůstat touto transmediací nedotčeny. $\mathrm{V}$ postupném rozvíjení schématu reprezentace média a transmediace (53-61) pak ukazuje, jak v utváření ekvivalentního mediátu různá technická média zprostř̀edkují různé typy smyslových konfigurací, přičemž ustálené mediální struktury mohou být realizovány jen některými modalitami, zatímco jiné je třeba překlenout konstelací modalit vlastních jen cílovému médiu. Model přitom nemůže přiliš znázornit rozdíl mezi jednoduchou a komplexní transformací. Může totiž docházet jen $\mathrm{k}$ přenosu jedné složky ustálené struktury média, například $\mathrm{k}$ již vícenásobně citované transmediaci kompozice příznačné pro určitou hudební formu do verbálního média, totiž do kompozice prozaického narativního díla - muzikalizace prózy ve Wolfově terminologii (WOLF 1999).

\section{Švankmajerovy a Elleströmovy možnosti dialogu}

Podívejme se, zda možnost metodologického sjednocení základny výzkumu mohou posílit ilustrační analýzy Švankmajerových animovaných filmů (kap. 5). Jak už bylo řečeno, nejedná se o případové interpretační studie, v nichž je sledované dílo cílem, nýbrž obráceně: analyzované dílo je tu prostředkem ukazování jednotlivých kategorií a postupů. Volba filmového materiálu je dána Elleströmovým školením ve filmové vědě i přesvědčením, že mnohoaspektovost uměleckého mediálního produktu jej předurčuje ke zkoumání komplexnosti transmediačních procesů. Konkretizace volby v tvorbě Švankmajerově je ostatně dobře zdůvodnitelná tvưrcovým trvalým tíhnutím k tématům vtělení, konzumace a proměny. Elleström vybírá trojí transformaci, v níž zdrojové médium představuje hudba (Johann Sebastian Bach: Fantasia g-moll, 1965), literatura (Žvahlav aneb Šatičky Slaměného Huberta, 1971) a konečně výtvarné umění (Možnosti dialogu, 1982). Ve všech třech př́kladech důkladně popisuje obsah a dílčí umělecké postupy sledovaného filmu (mimoděk tak stvrzuje reprezentační potenciál i nevyhnutelnou privilegovanost jazyka v diskurzu humanitních věd o mediálních vztazích).

V úvodu první analýzy Elleström poněkud překvapivě konstatuje, že všechny alternativy ustálených mediálních struktur ve vztahu k Bachově Fantasii nelze obsáhnout, protože jednotliví posluchači ve skladbě mohou shledávat odlišné 
rysy, a východiskem je tedy soustředit se jen na jejich omezený výběr (srov. 2014: 66). Domníváme se, že rozsah a povaha ustálených mediálních struktur by měly být vždy zdůvodnitelné intersubjektivně sdílenými kvalitami, oddělitelnými od individuálních konotací. Hudební skladba (Bachova Fantasia), která je předmětem filmové transmediace ( $v$ níž je současně celá skladba reprezentována jako složka audiální), s sebou podle Elleströma nese řadu indexikálních a symbolických podnětů, které se v naší mysli s určitou sumou předvědění spojují v kognitivní rámce: Skladba určená pro varhany se v západní hudební tradici asociuje s křestanstvím, s náboženským obřadem, jím zprostředkovanými procesy a událostmi, které s sebou často nesou proměnu, přepodstatnění, a s postoji a stavy vnímatele, jako je odpoutání od běžné zkušenosti, hluboká sebereflexe, atp. Fantasia má také řadu vlastností sdílených s jinými produkty téhož média (opakování, variace, kontrast), ale v souboru specifických kvalit, které Elleström nazývá ustálenými mediálními strukturami, se tyto vlastnosti asociují právě s výše uvedenými hodnotami a jejich prožitkem. Toto propojení vzniká nejen na základě vnímatelova předvědění, ale také na bázi podobnosti mezi smyslovým vnímáním emocí, duševních hnutí, a pohybu fyzického na jedné a určitých hudebních podnětů na druhé straně. Právě z těchto předpokladů mentální reprezentace (povznášející hudba a pomyslné odpoutání od světských záležitostí „se podobají“ pohybu vzhưru) vychází vizuální složka animovaného filmu. Je tu zřejmá paralela mezi kompozicí hudební skladby a jednotlivými částmi filmu, mezi rytmem skladby a rytmem střídání a pohybu obrazů, pozorujeme tu jak ikonicitu vizuálních reprezentací (pocit rozpínání ducha znázorněný v rozpínání tvarů, otvírání oken a dveří až $\mathrm{k}$ úplné volnosti v zobrazení nebe nad horizontem), tak jejich symboličnost danou tradicí jejich užití v kultuře. Elleström zdůrazňuje, že tento př́klad současně odhaluje rozdílnost zdrojového a cílového média: i přes komplexnost transmediace ji vnímáme jen jako přenos určitého (byt podstatného) výběru z ustálených mediálních struktur zdrojového média a specifických vlastností mediátu.

V analýze Žvahlava vychází Elleström z toho, že přes tradiční chápání zdrojového textu jako ukázky nonsensové poezie vykazuje celek aspekty narativní strukturace a s ní spojené obecné (byṫ v nadsázce, groteskně pojaté) rysy, jako jsou hrdinská konfrontace s převahou síly a násilím, napínavé situace a rázné činy. Všechny tyto aspekty jsou v transmediaci zvýrazněny úvodní dětskou deklamací veršů (jde tedy o zvukovou transmediaci tištěné básně), některé $z$ nich pak paralelně i následně v převážně ikonické vizualizaci, totiž filmové animaci. Elleström si všímá ikonických reprezentací jednotlivých věcných prvků zdrojového textu 
(Švankmajer uvádí opakovaně až refrénovitě na scénu - symbolicky černou kočku vybavenou stejně jako netvor z básně „drápy“ a „zuby“; kočka vystupuje jako ztělesnění jedné $\mathrm{z}$ destruktivních sil reprezentovaného světa a v závěru je „zneškodněna“, lapena v kleci) i větších narativních sekvencí. Je to právě narativní struktura, která tentokrát na rozdíl od předchozího př́kladu převádí výklad od analytické ilustrace až na rovinu interpretace: $v$ rovině symbolického významu vnímá Elleström narativní strukturaci transmediace jako komplexní výraz tématu vzpoury vůči otcovské autoritě. Uzávorkován je přitom ovšem kontext českého surrealismu, dominantním pretextem zůstává pro interpreta nepřekvapivě Carrollova báseň. Výsledky transmediace ustálených mediálních struktur Elleström shledává nejen ve vrstvě tematické, ale i v rovině označujícího: jako vizuální, prostorový ekvivalent básnických neologismů chápe ty sekvence, v nichž se kostičkové puzzle skládá ze známých částí do nebývalých kombinací a znovu vrací $\mathrm{k}$ řádu koherentních obrazů.

Právě na tomto příkladu si dovolíme názorně předvést problematičnost vztahu transmediační analýzy s rozborem filmové poetiky: Prostředek interpretovaný z první pozice jako určitá vizuální analogie jazykové povahy pretextu (kostky skládanky jako ztělesnění prvků celku podléhajících určitým zákonitostem uspořádání $\mathrm{v}$ případě, že celku má být přikládán smysl, tj. kostky zastupující znaky jazykové) může být z pozic poetiky filmového díla, zvláště pak autorské, vykládán jen jako rekvizita děsivě hravého-žravého fikčního světa zabydleného dekomponovanými staromódními hračkami a dalšími skurilními objekty, nebo jako jeden $\mathrm{z}$ materiálních prostředků dobře umožňujících vyjádřit všeobjímající (autorsky, švankmajerovsky) typické gesto stálé proměny. Chceme tím říci, že tyto funkce jsou v perspektivě filmologa nejspíš dostatečně autonomní z hlediska tvorby významu i dostatečně homogenní s celkem filmového díla na to, aby jej jako případné projevy transformačních strategií už nezajímaly. Obdobný příklad můžeme doložit ze seminární debaty nad jednou z novějších filmových adaptací Pýchy a predsudku Jane Austenové (režie Joe Wright, 2005). Pro románové vyprávění je příznačné, že vypravěč „přejímá“ či „reprodukuje“ obecně sdílené, společenským zařazením nositelů předurčené názory; jedním z nich je ostatně uveden celý román, a stejně jako v celém románu je i tento názor jemně ironizován. V diskusi v rámci intermediálního semináře - soustředěni na transmediační strategie - jsme nalezli ve filmové verzi řadu prostorových konstelací postav a jejich souladného jednání (popřípadě nejednání a statičnosti), které lze interpretovat jako vizualizace, ikonické reprezentace vypravěčského zobecňování postojů, mínění a zvyklostí (a jejich ironizace v nadsázce či kon- 
trastu). Jinak řečeno domnívali jsme se, že nacházíme prostředky transmediace vlastností původního vypravěčského diskurzu, které jsou jim adekvátní a současně v souladu s reprezentacemi světa příběhu: Např́klad až komicky secvičeně působící výjev v salónu, v němž dámy Bennetovy povstávají s vyšíváním v rukou, aby přivítaly vzácného hosta; obdobně týmový výjev jejich usedání v salonu Bingleyových, který naopak odhaluje jejich sdílenou, společensky nepřípadnou všetečnost a bažení po luxusu. A oproti tomu dokonalé rozmístění ustrnulých sourozenců Bingleyových a pana Darcyho, kteři se stávají živým ztělesněním řádu a distingovanosti vyšších vrstev i živou duplikací idejí symetrie a proporcionality vlastní georgiánské architektuře sídla. Přítomný zástupce adaptačních studií, kolega Petr Bubeníček, ovšem tytéž vlastnosti přisuzoval spíše vlivu žánrového okolí díla, tj. poetice tzv. heritage cinema s typickým zobrazováním ušlechtilých sídel v souznění s krajinou a figurou. Můžeme ostatně odkázat také k obecnému tíhnutí filmu k efektním, byt leckdy jen doprovodným či dokonce významově redundantním scénám, realizovaným $s$ až manifestním využitím možností média (media foregrounding): Platí to pro zvýraznění a střídání perspektiv ve scéně zabezpečování sídla pana Darcyho po skončení letní sezóny (v níž ještě mohou působit funkčně, jako prostředek podtržení atmosféry ukončení časového období i jistého naladění, loučení a předjímání nostalgického prožitku apod.), nebo jako je už jen čistě formální mediální hra s průchodností interiéru v samém úvodu příběhu, v němž kamera provází postavu Elizabeth i „skrze zdi“ jejího rodného domu. $V$ této diskusi sice nedošlo $\mathrm{k}$ žádnému metodologickému rozkolu, avšak podrobná analýza transmediačních strategií se z pohledu adaptačních studií mohla jevit poněkud zbytná. Uzavřeme proto tento exemplifikační exkurz konstatováním, že z perspektivy intermediální i filmové se nám otvírá celý vějiř alternativních argumentů, které si neprotiřečí: na obou stranách jsou totiž napojeny jak na aspekty ustálených mediálních struktur (argumentace vlivem filmové školy či žánru ze strany adaptačních studií) nebo strategie jejich transmediace (intermediální pohled zaostřený právě na onen pomyslný transfer mezi médii), tak současně na kulturní zdroje náležející k historickému zázemí literárního pretextu. Smír tu zajištuje fakt, že generované významy jsou si blízké, at už jsou vlastnosti cílového mediálního produktu výsledkem transmediace jedné složky zdrojového média, nebo výsledkem relativně neodvislého aktu reprezentace.

Poslední, nejpopisnější Elleströmova analýza se zaměřuje na transmediaci reprezentací s dominantní modalitou prostorovou (Arcimboldových kompozitních portrétů) do animovaného filmu, tedy média, v němž se podstatně uplatňuje 
modalita temporální. Nepřehlédnutelnou vlastností transmediace i její analýzy je tu zjevně skutečnost, že kompozitní povaha portrétů ve zdrojovém médiu je v souladu se se Švankmajerovým až obsedantním zájmem o bytí a transformaci hmoty (nebo ještě spíše o transformaci jako způsob bytí hmoty) a animace se tak ukazuje jako optimální mediální technika pro realizaci tematického souběhu.

Elleströmovy analýzy tak nepochybně ujištují o smysluplnosti jeho postupu ty stoupence intermediálních studií, které zajímají obecné mechanismy i individuální projevy transformačních procesů mezi kvalifikovanými médii. Ve vztahu k jednotícímu metodologickému záměru však jejich konkrétní argumenty nenabývají dostatečné přesvědčovací síly.

\section{Mapování prostoru, tentokrát podrobně}

Další z cest k vyhodnocení potenciálu Elleströmovy nejnovější práce je prověření jeho vlastních kritických stanovisek, jež jsme bez ohledu na jejich postavení $\mathrm{v}$ úvodu monografie záměrně odsunuli. Autor se kriticky dotýká jen několika vybraných teorií intermediality: jako jeden $\mathrm{z}$ jejích mezníků, předcházející konceptualizaci transformace médií, uvádí Clausem Clüverem zavedený pojem intersémiotické transpozice (1989), nepřehlédnutelně spojený s „interartovou“ fází intermediálních studií, $\mathrm{v}$ nichž dominantním objektem pozorování byla individuální umělecká díla zkoumaná nejčastěji na pozadí vizuálního a verbálního znakového systému.

Z hlediska Elleströmova literárněvědného zázemí trochu překvapivě, $z$ hlediska popularity prací věnovaných vztahům mezi médii nepřekvapivě tu zazní titul autorské dvojice Bolter a Grusin, Remediation. Understanding New Media (1999). Jak naznačuje její podtitul, jejím záměrem bylo zpřehlednit situaci, v níž v důsledku radikálního zásahu digitálních médií došlo $\mathrm{k}$ proměnám v nejrůznějších oblastech reprezentace a komunikace. Autoři vedle sebe postavili dvojí vývojový pohyb, který je současně obousměrný: Zaprvé je to pohyb vyjádřený eponymním pojmem remediace, tj. proces vývoje nových médií na základě starých, který působí i zpětně - „stará“ média se transformují pod vlivem nových. Druhý pohyb, který je vlastně jeho specifikací, je tíhnutí nových médií k potlačování zprostředkovanosti, tedy $\mathrm{k}$ mediální transparentnosti (v současnosti ji nejlépe reprezentují virtuální a rozšířená realita). Zdánlivě protichůdně pak pracuje tendence 
k tematizaci zprostředkovanosti, reprezentaci mediality. Nově vytvořený komunikační prostor je totiž oblastí nevyhnutelné interakce nových médií se „starými“, a ta se často manifestuje právě jejich tematizovanou přítomností, vícenásobnou reprezentací v soustavě odkazů odpovídající hypertextové struktuře (počítačová aplikace dovoluje takto usouvztažnit text, schéma, fotografii, tradiční animaci apod.) - Bolter a Grusin ji označují jako hypermediaci. Konkrétní podoby remediace a hypermediace pak popisují podle jednotlivých zdrojových médií a uživatelských přístupů (digitální fotografie, počítačová hra apod.). Nezajímají je tudíž komplexní mechanismy transformací mezi různými sémiotickými systémy, nýbrž spíše to, co bychom mohli s využitím Elleströmova pojmosloví nazvat funkčním transferem ustálených mediálních struktur v rámci remediace (například přenos lineární perspektivy z malířství do trojrozměrných digitálních vizualizací). Asi nejradikálnější myslitelnou změnu zasahující médium verbální, totiž rozvětvení tradičního lineárního uspořádání textu ve strukturu hypertextovou (které by mohlo podstatně zasáhnout pojetí literární tvorby a její recepce), řeší autorská dvojice jen jako práci se sítí odkazů různého typu. Narážíme tu na problém, se kterým se v teoretizaci média, mediálních transformací a dalších mediálních vztahů setkáváme vždy znovu: text, a to zvláště text literární, stojí často na okraji zájmu badatelů. Je proto vlastně zbytečné pozastavovat se spolu s Elleströmem nad rozpětím pojmu remediace: vychází z potenciálu nových médií, jeho specifikace jsou pak dány hlavně parametry jednotlivých digitálních submédií a jejich užití.

Úsilí směřující k systemizaci jevů nachází naopak Elleström v zásadě ve všech pracích Wernera Wolfa, typického reprezentanta „literaturocentrických“ intermediálních studií, at už jsou primárně zaměřeny na konkrétní projev intermediality, jako je počáteční muzikalizace prózy (1999) nebo směřují k teoretizaci jevů (2002, č. 2011; 2002a). Elleström zprvu hledá styčné body mezi Wolfovým a vlastním rozvržením systému: dovozuje, že jeho rozlišení kombinace a integrace médií na jedné straně, a transformace médií na straně druhé zhruba odpovídá Wolfově diferenciaci mezi zjevnou (overt) a skrytou (covert) intermedialitou. - Už ale nevíme, zda Wolfova kombinace médií - tj. např́iklad relativně volné spojení literárního textu a knižních ilustrací schopných samostatného fungování - opravdu odpovídá Elleströmovu chápání kombinace; zdánlivá konkurence pojmů totiž namnoze bývá pouhým souběhem odlišných termínů. - Elleström však především namítá, že Wolfovou podmínkou zjevnosti je rozlišitelnost intermediality $v$ povrchové vrstvě mediálního produktu, aniž by bylo řečeno, co se 
povrchovou vrstvou míní, například u takového filmu. Oponovat můžeme tím, že Wolf povrchovou vrstvu objasňuje jako rovinu signifikantů, která se nám ukazuje jako heterogenní či dokonce hybridní (tzn. že její jednotlivé složky nelze izolovat bez ztráty významu, což nepochybně platí třeba pro film, srov. WOLF 2011: 69). Lze se také domýšlet, že výraz „povrchová vrstva“ má vzhledem k Wolfovu pojetí média jako mj. distinktivního kognitivního rámce (srov. WOLF 2011: 63) svůj aspekt kognitivní, a vztahuje se k aktu rozpoznání média či mediálního produktu. S jistou nadsázkou jí můžeme podložit i poněkud triviálně znějící formulaci „zřejmá na první pohled“, kdy pohled je samozřejmě synekdochou dalších způsobů vnímání; trivialitu tohoto vyjádření ostatně snadno odstraní analýza, která oprávněnost „prvního pohledu“ potvrdí nebo vyvrátí.

Jak už zmíněno, zvlášt kriticky se Elleström staví k Wolfovu dělení intermediality na strukturní a relační (werkintern a werkübergreifend, in WOLF 2002, č. 2011, intracompositional a extracompositional, in WOLF 2002a). Již zmiňovaná muzikalizace prózy je v tomto pojetí strukturní intermedialitou (respektive implicitní intermediální referencí, kterou rozklíčujeme ve chvíli, kdy se zabýváme kompozicí díla), zatímco převod románu do operního díla je projevem relační intermediality. Podle Elleströma se tím tvrdí, že zatímco některé intermediální rysy nacházíme uvnitř mediálních produktů, jiné mimo ně a médium tak ve výsledku nabývá nežádoucího charakteru „nádoby“ se zjevným „povrchem“a „obsahem“. Zaprvé autor sám se tomuto dělení, jak již bylo připomenuto, vyhnout nedokáže. Zadruhé je třeba rozumět Wolfovu systému jako výsledku určité fáze intermediálních studií a individuálnímu projevu onoho „myšlení o médiích“. Intermedialita sama je přece ze své povahy naukou „o vztazích“ - a soustředění na vztah sám je v kodifikační fázi (jíž nepochybně přelom tisíciletí byl) do jisté míry ještě dědictvím předchozí fáze vývoje, totiž interart studies, která se od tradiční komparace umění posunula $\mathrm{k}$ interdisciplinární konfrontaci jednotlivých mediálních produktů a od ní k uvědomění potřeby popsat mechanismy intersémiotických vztahů. Do té doby nesamozřejmá „medialita“ uměleckých děl tak vyvstala jako důsledek srovnávací perspektivy pozorování a teprve jim „přidělila" status mediálních produktů.

Obě klasifikace lze proto celkem snadno smírit upřesněním některých aspektů Wolfova výkladu. Jestliže si do vzorce relační intermediality vsadíme jako typický předmět dva mediální produkty, ozřejmí se nám, co má Wolf na mysli: opět spíše onu srovnávací perspektivu, pozorovatelské „navazování vztahu“ mezi produkty. A zde máme vysvětlení, proč je v jeho koncepci intermediální transpozice (tj. transmediace u Elleströma) subformou relační intermediality: 
relací tu rozumí prokazatelnou genetickou souvislost mezi signifikáty obou děl realizovaných následně $\mathrm{v}$ různých médiích, která je zřejmá ze srovnání těchto děl. Připomíná přitom, že „v praxi však pro recipienta není znalost této filiace bezpodmínečně nutná $\mathrm{k}$ pochopení smyslu, zprostředkovaného postmédiem. Intermediální vztah bývá v postmédiu často - pokud vůbec - zachycen jen okrajově (např. poznámka ,podle románu... autora...'v titulcích filmu), nebot' transpozice vede $\mathrm{k}$ samostatné znakové konfiguraci podle měřítek postmédia (což vysvětluje např. relativní samostatnost filmů natočených podle literárních předloh). Existence intermediality není proto v případě intermediální transpozice relevantní pro bezprostřední generování smyslu daného díla“ (WOLF 2011: 67). Uvědomme si, že Wolfova perspektiva se tu poněkud posouvá: je do ní promítnuta perspektiva vnímatele (například diváka filmové adaptace), který legitimně recipuje izolovaný produkt mediální transpozice bez reflexe jeho genetického vztahu k zdrojovému produktu či dokonce bez jeho znalosti. To ovšem neznamená, že z procesu recepce je tím zásadně vyloučena latentní př́tomnost povědomí o zdrojovém médiu; míní se tím pouze, že není v tomto procesu přímo aplikována. Nevidíme také důvod, proč intermedialitě strukturní připisovat fatální oddělení média a „vlastního obsahu“. Jde spíše o to, že i ona je relační: jestliže se intermediální povahy individuálního mediálního produktu dobereme analýzou jeho výstavby, v níž odhalíme transformaci postupů jiného média (např́klad muzikalizaci prózy jako přenos zákonitostí nějakého hudebního žánru do kompozice a tempa vyprávění), pak se tak může dít jen na základě našeho usouvztažnění aktuálních vlastností pozorovaného mediálního produktu s naším povědomím o vlastnostech druhého média, jeho žánrech atd.

Zdá se, že ve vztahu k této terminologické diskusi (stejně jako k řadě jiných) můžeme parafrázovat onu trefnou otázku, kterou v Lodgeově univerzitním románu Svět je malý klade účastníkům mezinárodní konference začínající badatel: „Co byste dělali, kdyby s vámi všichni souhlasili?" Prostor pro skutečný střet názorů a precizaci pojmů se otvírá v analytické praxi, v níž intermedialita nabízí základnu pro interdisciplinární vyjednávání z různých výchozích pozic - pokusili jsme se to ukázat už ve vyhodnocení rozboru Švankmajerova Žvahlava a v analogické exemplifikaci vlastností filmové transmediace románu Pýcha a předsudek.

U Iriny Rajewské, jejíž práce (2002) měla primárně úlohu deskriptivní a typologizační, zase Elleström odmítá rozlišení mediální transpozice a intermediální reference s tím, že tento rozdíl lze zvláště v praxi jen obtížně udržet a že druhá kategorie zahrnuje jevy přiliš heterogenní. Nemluví ovšem o tom, že tyto jevy Rajewská uvádí jako př́klady určitého odstupňování či míry souvztažnosti 
dotčených médií. Opět lze nabídnout smíření: maximální podobou reference je přece to, co Elleström nazývá komplexní reprezentací média (tedy například ekfráze, jejíž zahrnutí do oblasti reference Rajewské vytýká), zatímco minimální referencí to, co Rajewská ve své typologizaci nazývá zmínkou o médiu, tedy bodový kontakt s druhým médiem spočívající třeba v jeho prostém pojmenování.

Přestože se Elleström v zájmu konzistence svého zobecňujícího přístupu brání poukazu na interpretační důsledky konkrétních realizací tohoto jevu, ukážeme zde, že právě pouhá tematizace média může nabývat rozličných funkcí: V pohádce Michaela Endeho Př́běh, který nikdy neskončí (1979, česky 1987) se kniha čtená malým hrdinou transformuje v alternativní svět, v němž se zásadně transformuje i příběh protagonistův, zatímco v animované verzi Dickensovy Vánoční koledy (režie Robert Zemeckis, 2009) je sice kniha otvíraná na počátku zároveň se zazněním hlasu neviditelného filmového vypravěče, voice-over, „reprezentována“, ${ }^{8}$ avšak její funkcí je reference, a to nikoli k médiu, ale k literárnímu dílu samému, ba i k literární (a tedy šířeji i kulturní) tradici, která je s ním a celou Dickensovou tvorbou spojena. Tento postup lze proto chápat i jako strategii kulturní nobilitace animované verze: Zatímco dialogy postav zachovává tato transmediace pietně, $v$ realizaci vnějších dějových pasáží její tvůrci s chutí, až manifestně těží ze zobrazovacích možností média a žánrově příznačných akčních schémat plných nadsázky, jimiž atmosféru světa vyvstávajícího ze známé duchařské povídky střídavě zesilují a odlehčují. Anebo jiný příklad: zatímco v epizodě televizního seriálu ze současnosti je obvykle televizor přítomen jako vybavení bytu a „televize běží v pozadí“ jako rekvizita habituální, protože řada lidí má prostě ve zvyku automaticky ji zapnout po příchodu domů, ve filmu Noční hlídka (režie Timur Bekmambetov, 2004, adaptace stejnojmenného fantasy románu Sergeje Lukjaněnka z r. 1998, česky 2005) jsou reprezentace jiného média zásadně významotvorné. Např́iklad tematicky zdánlivě zcela mimoběžný televizní program o rybaření, na který mžourá polobdělý protagonista, obsahuje symbolickou interpretaci paralelně probíhajícího děje ${ }^{9}$, arkádová hra, kterou se baví jeho protivník, zase inscenuje soupeříí avatary obou postav a předvídá tak další dějový vývoj.

8) Reprezentací tu míníme jak knihu coby fyzický artefakt, tak literární text, reprezentovaný citací incipitu: „Pro začátek - Vodral byl nebožtík."Vzápětí však vypravěčský hlas umlká, do záběru se nasune obraz zesnulého Vodrala v rakvi s mincemi na očích a fikční svět zprostředkovaný audiovizuálním médiem se od knihou tematizovaného média verbálního zcela emancipuje.

9) Na výstižné př́íklady reprezentace média televize a jejího funkčního zapojení do řízení divákovy intepretace filmového děje upozornil v analýze této adaptace (2016) student intermediálního semináře Pavel Kopečný. 
Těmito příklady má být řečeno asi tolik: ve chvíli, kdy je pro badatelský záměr (nebo instruktivní výklad v semináři, v němž chceme zvyšovat senzitivitu studentů pro takové jevy) účelné soustavněji popsat, porovnat a utřídit intermediální jevy na průsečíku dvou os - škály sahající od prosté singulární reference až po komplexní reprezentaci na první ose, a škály jejich významotvorného potenciálu na ose druhé - je využití subtilní (tu více, tu méně) popisné klasifikace Iriny Rajewské na místě, minimálně jako metodologická základna pro naši vlastní, alternativní klasifikaci. Připustíme-li, že reference jsou jistými stupni reprezentace (což ostatně Elleström implicitně činí ve výčtu možných reprezentací, jako jsou citace, narážka apod., srov. 2014: 28), pak se můžeme snadno dohodnout na tom, že nejde o zásadní rozpor v pojetí, nýbrž převážně o rozdílnou míru zájmu obou autorů na třídění hlavních kategorií.

Jak tato pojmoslovná konfrontace, tak předchozí materiálové sondy a rekapitulace zkušeností z diskusí ukazují, že pověstným jablkem sváru není částečné překrývání pojmů $\mathrm{z}$ různých systémů či vágní vymezení pojmů v rámci některých z nich, ale primárně rozdílnost badatelských zájmů. Některé odlišnosti jsou nepřekvapivě dány jen úhlem pohledu, zatímco další souvisejí s tím, že zdánlivě podobný předmět zkoumání se jeví „jiný“ vzhledem k odlišnosti badatelského cíle. Ukazuje se však také, že v onom „širokém poli“ intermediálních výzkumů se posouvá i zažitý či spíše typický vzorec humanitních věd: odlišná stanoviska jsou podstatně provázána nejen s příslušnou fází vývoje intermediální metody, ale také s dynamickým rozvojem jejího předmětu, s nutností vyrovnat se s leckdy zcela novými mediálními fenomény vyvstalými v důsledku razantních proměn technologií a komunikačních platforem. Dobře patrné je to například na tom, jak významně „zastaraly“ některé výklady z příspěvku autorské dvojice Bolter a Grusin (1999).

Tato relativizace platí i pro účel intermediálního projektu: Budeme-li usilovat o ono (stále poněkud utopicky znějící) vytvoření společné platformy (inter) mediálních studií, můžeme se pokusit podpořit návrh Elleströmův. Pokud bude naším záměrem popsat inventář nejrůznějších projevů intermediality ve sféře umění, jistě se spokojíme s některými názornými až explikativními pojmy Rajewské. A budeme-li chtít setrvat co nejblíže východisku a středobodu zájmu literární vědy, kterým (snad stále ještě) zůstává literární text, poradíme se s Wernerem Wolfem.

Článek vznikl v rámci projektu Literární komunikace ve světle „média“, GA ČR 16-11101S. 
Alice Jedličková

Jeden model, různé zájmy. Konvergence a divergence intermediálních studií

\section{LITERATURA}

ABBOTT, Horace Porter

2002 The Cambridge Introduction to Narrative (Cambridge: Cambridge University Press)

BARBETTI, Claire

2011 Ekphrastic Medieval Visions. A New Discussion in Interarts Theory (Basingstoke and New York: Palgrave Macmillan)

BOLTER, Jay David - GRUSIN, Richard

1999 Remediation. Understanding New Media (Cambridge MA and London: MIT Press)

CLÜVER, Claus

1989 „On Intersemiotic Transposition“, Poetics Today 10, s. 55-90

ELLESTRÖM, Lars

2010 „The Modalities of Media: A Model for Understanding Intermedial Relations“, in Lars Elleström (ed.): Media Borders, Multimodality and Intermediality (Basingstoke and New York: Palgrave Macmillan), s. 11-48 2014 Media Transformation. The Transfer of Media Characteristics Among Media (Basingstoke and New York: Palgrave Macmillan)

FEDROVÁ, Stanislava - JEDLIČKOVÁ, Alice

2008 „Ekfráze: deskripce vs. narativ“, in Alice Jedličková - Ondřej Sládek (eds.): Vyprávění v kontextu (Praha: Ústav pro českou literaturu AV ČR), s. 119-139

2011 „Konec literárního špenátu aneb Popis v intermediální perspektivě“, Česká literatura 59, č. 1, s. 26-58 2016 „Kontexty: rétorika a teorie ekfráze“, in Stanislava Fedrová - Alice Jedličková: Viditelné popisy. Vizualita, sugestivita a intermedialita literární deskripce (Praha: Akropolis), s. 169-182

2016a „Kontexty: intermediální poetika“, in Stanislava Fedrová - Alice Jedličková: Viditelné popisy. Vizualita, sugestivita a intermedialita literární deskripce (Praha: Akropolis), s. 184-221.

LUND, Hans - LAGERROTH, Ulla-Britta - HEDLING, Erik

1997 Interart Poetics. Essays on the Interrelations of the Arts and Media (Amsterdam - Atlanta: Rodopi)

HUTCHEON, Linda

2006 A Theory of Adaptation (New York: Routledge)

JEDLIČKOVÁ Alice

2011 „Tanec intermediality“, Česká literatura 59, č. 5, s. 737-742

2011a „Intermediální poetika př́běhu“, in Stanislava Fedrová - Alice Jedličková (eds.): Intermediální poetika př́běhu (Praha: Ústav pro českou literaturu AV ČR - Akropolis), s. 5-25

JENKINS, Henry

2006 Convergence Culture. Where Old and New Media Collide (New York: New York University Press) 
McFARLANE, Brian

1996 Novel to Film. An Introduction to the Theory of Adaptation (Oxford: Clarendon Presss)

RAJEWSKY, Irina O.

2002 Intermedialität (Tübingen - Basel: Francke)

RIPPL, Gabriele (ed.)

2015 Handbook of Intermediality. Literature - Image - Sound - Music (Berlin - Boston, Mass.: de Gruyter)

SZYMBORSKA, Wisława

2009 Okamžik. Dvojtečka. Tady. Přel. Vlasta Dvořǎčková (Příbram: Pistorius \& Olšanská)

The Sonnet Project NYC, http://sonnetprojectnyc.com/, přistup 20. 8. 2017

WOLF, Werner

1999 The Musicalization of Fiction. A Study in the Theory and History of Intermediality (Amsterdam and Atlanta, GA: Rodopi)

2002a „Intermediality Revisited: Reflections on Word and Music Relations in the Context of a General Typology of Intermediality“, in S. M. Lodato - S. Aspden - W. Bernhart (eds.): Essays in Honor of Steven Paul Scher and on Cultural Identity and the Musical Stage (Amsterdam and New York: Rodopi), s. 13-34

2011 [2002] „Intermedialita: široké pole výzkumu a výzva literární vědě“, Česká literatura 59, č. 1, s. 62-85

2013 [2007] Popis jako transmediální modus reprezentace. Přel. Olga Richterová, ed. Alice Jedličková (Praha: Ústav pro českou literaturu AV ČR)

YACOBI, Tamar

1995 „Pictorial Models and Narrative Ekphrasis“, Poetics Today 16: 4, s. 599-649

Doc. PhDr. Alice Jedličková, CSc., jedlickova@ucl.cas.cz, Ústav pro českou literaturu AV ČR, Česká republika / Institut of Czech literature of the Czech Academy of Sciences, Prague 